\title{
STRATEGI UMPAN BALIK SEBAGAI ALTERNATIF STRATEGI pembelajaraNs penerapan dan tantangan
}

\author{
TIARA ELIZA \\ Universitas Palembang \\ tiaraeliza90@gmail.com
}

Pertama Diterima: 22 Februari 2019

Bukti Akhir Diterima: 24 September 2019

\begin{abstract}
Abstrak
Dewasa ini perkembangan dunia pendidikan sangatlah pesat. Masuknya teknologi dan modernisasi semakin menambah dinamika perkembangan strategi pembelajaran dan pengajaran. Terdapat beragam cara dan strategi pembelajaran yang diterapkan oleh para tenaga pengajar. Salah satunya adalah strategi umpan balik. Oleh karena itu, tulisan ini dibuat bertujuan agar menjadi salah satu referensi dalam mengembangkan strategi belajar pengajar demi mencapai pendidikan yang berkualitas. Adapun metode yang digunakan adalah deskriptif kualitatif analisis. Hasil penelitian ini menunjukan bahwa strategi umpan balik memberikan hasil yang positif dalam mencapai tujuan pembelajaran yang telah ditetapkan.
\end{abstract}

Kata kunci: Strategi Umpan Balik, Penerapan, Tantangan

\begin{abstract}
Today the development of the world of education is very rapid. The entry of technology and modernization increasingly adds to the dynamics of the development of learning and teaching strategies. There are various ways and learning strategies applied by the teaching staff. One of them is a feedback strategy. Therefore, this paper is intended to be one of the references in developing instructional learning strategies in order to achieve quality education. The method used is descriptive qualitative analysis. The results of this study indicate that the feedback strategy provides positive results in achieving the stated learning goals.
\end{abstract}

Keywords: Feedback Strategy, Implementation, Challenge

\section{PENDAHULUAN}

Secara umum, strategi merupakan konsep yang cukup populer, sejak zaman dahulu sampai sekarang. Sering kita mendengar konsep strategi sebagai pembicaraan umum, dimana strategi merupakan sesuatu cara, langkah-langkah yang dirumuskan secara matang sebelum melakukan sesuatu dengan harapan mendapat hasil yang maksimal. Dalam hal ini jika kita kaitkan dengan strategi belajar mengajar atau pembelajaran, yang dimaksud dengan strategi belajar mengajar adalah suatu cara yang dirancang oleh pengajar dalam rangka mencapai hasil yang diinginkan atau dengan kata lain strategi/cara yang digunakan dalam mengajari peserta didik untuk belajar secara maksimal 
agar hasil belajar lebih optimal. Hal ini dimaksudkan sebagai pola yang ditetapkan pengajar sebelum mengajar agar mendapatkan hasil yang maksimal.

Hal ini sesuai dengan pendapat Sudjana (1989) yang mengatakan bahwa strategi belajarmengajar merupakan tindakan guru melaksankan rencana mengajar, yaitu usaha guru dalam menggunakan beberapa variable pengajaran (tujuan, metode, alat, serta evaluasi) agar dapat mempengaruhi siswa mencapai tujuan yang telah ditetapkan. Kemudian Sunhaji (2008) juga mengungkapkan bahwa strategi pembelajaran merupakan cara-cara yang akan dipilih dan digunakan oleh seorang pengajar untuk menyampaikan materi pembelajaran sehingga akan memudahkan peserta didik menerima dan memahami materi pembelajaran, yang pada akhirnya tujuan pembelajaran dapat dikuasainya di akhir kegiatan belajar. Oleh karena itu strategi belajar mengajar merupakan sejumlah langkah yang direkayasa sedemikian rupa (oleh pendidik) untuk mencapai tujuan pengajaran tertentu, Pupuh dan Sobri (2009).

Berdasarkan uraian di atas dapat kita maknai bahwa strategi belajar mengajar begitu penting untuk dirumuskan pengajar sebelum melaksanakan pembelajaran, serta perlu melakukan penyusunan ulang bila tidak sesuai dengan kondisi kelas, situasi kelas, karakteristik siswa yang ditemui dan materi yang akan diajarkan karena seperti yang kita ketahui tugas utama para pendidik adalah membimbing para peserta didik untuk mendapatkan hasil pembelajaran secara optimal, sedangkan mereka memiliki karakteristik /cara belajar yang berbeda-beda untuk dapat memahami materi yang telah disampaikan. Dalam mengatasi situasi tersebut, para pengajar/pendidik diharapkan dapat memiliki kemampuan dalam memilih strategi yang tepat untuk mencapai tujuan yang telah ditentukan. Oleh sebab itu, tulisan ini membahas strategi umpan balik yang dapat dijadikan salah satu alternatif strategi mengajar yang dapat digunakan oleh para pendidik/pengajar dalam melaksanakan proses pembelajaran.

\section{HASIL PENELITIAN DAN PEMBAHASAN}

\section{Strategi Umpan Balik Sebagai Metode Mengajar}

Menurut Windarsih (2016) umpan balik merupakan sebuah cara yang dilakukan oleh pendidik untuk membantu peserta didik dalam memahami suatu pembelajaran dengan cara menanggapi hasil suatu pembelajaran yang dilakukan sampai peserta didik menguasai materi yang telah disampaikan. Hal ini dilakukan karena mengingat peserta didik merupakan individu yang memiliki kemampuan berbeda-beda dalam memahami pelajaran. Ada yang cepat, ada yang lambat. Faktor intelegensi yang berbeda-beda menjadi salah satu indikator dalam kelancaran mengikuti proses belajar mengajar. Kemampuan yang berbeda mengakibatkan waktu untuk mencapai tujuan belajar mengajar berbeda pula. Untuk mengatasi perbedaan tersebut maka diperlukan metode mengajar yang tepat. Metode mengajar sebagai strategi dalam mencapai tujuan belajar mengajar harus dipilih dan ditentukan lebih dahulu sebelum diselenggarakan kegiatan belajar mengajar.

Dalam hal ini para pendidik dapat menentukan lebih dari satu tujuan belajar mengajar dengan menggunakan beberapa metode mengajar. Dalam prakteknya para pendidik sering membuat kombinasi dari beberapa metode mengajar guna mempermudah percapaian tujuan belajar mengajar. Salah satunya dengan menggunakan strategi umpan balik. Umpan balik (feedback) adalah 
pemberian informasi yang diperoleh dari tes atau alat ukur lainnya kepada peserta didik untuk memperbaiki pencapaian hasil belajar, Suke dalam Windarsih (2016).

Dalam kaitan dengan pembelajaran, Irons dalam Haryoko (2011) mengemukakan bahwa umpan balik adalah setiap informasi, proses atau aktivitas yang dilakukan untuk mempercepat siswa belajar yang didasarkan pada hasil penilaian perkembangan peserta didik. Dari beberapa hasil penelitian yang ada menggambarkan bahwa korelasi positif antara keselarasan kemampuan siswa dalam memahami materi dengan penggunaan umpan balik yang efektif. Pemberian umpan balik tepat waktu akan sangat mempengaruhi proses belajar mengajar menjadi lebih efektif, Steven dan Levi (2005). Oleh karena itu, sangatlah penting menerapkan strategi umpan balik dalam kegiatan pembelajaran yang merupakan peristiwa yang dapat memberikan kepastian kepada peserta didik dan pendidik bahwa kegiatan belajar telah atau belum mencapai tujuan.

\section{Penerapan Strategi Umpan Balik}

Sesuai dengan Peraturan Menteri Pendidikan Nasional Nomor 41 tanggal 23 November 2007, Standar Proses Pendidikan secara rinci terdiri dari pola kegiatan pendahuluan, kegiatan inti, dan kegiatan penutup. Proses yang sama juga dikemukakan oleh Dick dan Carey (1994) yang menyebutkan bahwa terdapat 5 komponen strategi pembelajaran, yaitu (1) kegiatan pembelajaran pendahuluan, (2) penyampaian informasi, (3) partisipasi peserta didik, (4) tes, dan (5) kegiatan lanjutan.

Melalui kedua proses yang telah dikemukan di atas penerapan strategi umpan balik dalam hal ini dilaksanakan pada kegiatan penutup atau kegiatan lanjutan. Kegiatan yang dikenal dengan istilah follow up dari suatu hasil kegiatan yang telah dilakukan seringkali tidak dilaksanakan dengan baik oleh para tenaga pendidik.

Menurut Roper dalam Windarsih (2016) pelaksanaan umpan balik (feedback) dapat dibedakan menjadi empat tingkat:

Tingkat 1: Umpan balik (feedback) berupa keterangan salah atau benar. Dalam hal ini bentuk kegiatan adalah pelakasanaan tes atau kuis yang dilakukan pada pertemuan selanjutnya yakni seminggu setelah pemberian materi. Pelaksanaan kuis ini biasa dilakukan 15 menit pertama sebelum memulai materi selanjutnya. Adapun bentuk pelaksanaan tes ini dapat dilakukan dengan lisan atau tertulis. Setelah selesai pelaksanaan tes, kemudian hasil tes akan dikembalikan kepada semua peserta didik.

Tingkat 2 dan 3: Umpan balik berupa pemberian jawaban yang benar dan ditambah penjelasan. Pada pelaksanaan umpan balik di tingkat 2 dan 3 ini, pendidik dan peserta didik bersama-sama melakukan pembahasan hasil tes. Pendidik mengoreksi, memberikan jawaban yang benar dan menambahkan penjelasan terhadap materi tes tersebut, disis lain para peserta didik juga diberikan kesempatan untuk memperbaiki jawaban yang salah. Setelah itu, peserta didik diberikan penilaian terhadap hasil tes mereka masing-masing. Dalam pelaksanaan umpan balik ini dapat dirumuskan 3 implikasi yakni: 
1. Penilaian dari sudut pandang pendidik, setelah 3 kali pelaksanaan tes/kuis maka akan memberikan sebuah prediksi/penilaian kepada pendidik mengenai persentase pemahaman peserta didik apakah telah mencapai standar kelulusan atau belum. Dengan kata lain hasil tes/kuis akan menjadi evaluasi bagi pengajar/pendidik karena hasil yang diperoleh dapat menunjukan penguasaan dan pemahaman materi yang telah disampaikan pada pekan yang lalu. Hal ini sesuai dengan manfaat dari penerapan strategi umpan balik seperti yang diungkapkan oleh Suherman dalam Windarsih (2016) yakni penerapan umpan balik dapat mendorong pendidik untuk menilai seberapa relevansi antara aspek-aspek pembelajaran dengan tingkat kemampuan siswa dalam menguasai bahan ajar/materi seperti yang telah ditetapkan dalam tujuan pembelajaran.

2. Penilaian dari sudut pandang pesesta didik. Adapun penilaian yang dimaksud adalah hasil tes/kuis dapat menjadi sebuah ukuran dan prediksi nilai ujian tengah semester yang akan diperoleh para peserta didik. Hal yang sama juga dikemukakan oleh Suherman dalam Windarsih (2016) mengenai manfaat dari penerapan strategi umpan balik yakni dapat membantu peserta didik untuk menilai kemampuan yang tidak bisa dilihat dan dirasakannya sendiri.

3. Memberikan motivasi, penguatan (reinforcement) atau hukuman (punishment) dan penghargaan (reward) menurut Harsono (1988) dan Apruebo (2005) dalam Windarsih (2016). Setelah para peserta didik mendapatkan gambaran mengenai kemampuan yang mereka miliki hal tersebut akan menjadi daya dorong atau motivasi bagi peserta didik yang masih merasa belum mencapai nilai standar, mereka akan terpacu untuk menjadi lebih baik lagi pada tes selanjutnya. Kemudian para peserta didik juga akan diberikan hukuman apabila nilai tes yang mereka dapat tidak mencapai standar. Untuk aturan pemberian hukuman ini bersifat opsional atau tergantung kepada pengajarnya masing. Dengan adanya pemberian hukuman maka secara otomatis juga akan diberikan penghargaan. Pelaksanaan pemberian penghargaan ini dapat berupa pemberian nilai bagi para peserta didik yang mencapai target kelulusan yang telah ditetapkan sebelum pelaksanaan tes.

Tingkat 4: Umpan balik pada tingkat 4 diberi pengajaran atau konsep tambahan untuk menguatkan. Setelah para tenaga pengajar atau pendidik mengetahui prediksi tentang penilaian dan pemahaman peserta didik mengenai materi yang telah disampaikan maka dalam hal ini sangatlah penting para tenaga pengajar/pendidik segera mengambil tindakan antisipatif diantaranya adalah membuat dan menentukan kelompok belajar berdasarkan kategori tingkat pemahaman peserta didik dengan menerapkan sistem belajar kelompok yang diselenggarakan di luar jam belajar mengajar. Pengajar/pendidik memilih dan mengatur kelompok-kelompok belajar yang nantinya akan di isi oleh 1 atau 2 org mentor sebaya. Adapun mentor sebaya yang dimaksud adalah salah satu peserta didik yang memiliki pemahaman lebih terhadap materi dari kelas yang bersangkutan atau pun dari kelas lain. Peran mentor sebaya di sini sangat penting yakni sebagai pembimbing, pengawas dan pengganti sementara pengajar selama belajar kelompok berlangsung. Disisi lain Pendidik/tenaga pengajar juga telah mempersiapkan soal-soal latihan dan mendistribusikannya kepada setiap kelompok. Dalam hal ini para pendidik/tenaga pengajar harus mempersiapkan dan menyediakan waktu untuk mengontrol dan membimbing setiap kelompok jika peserta didik menemui kesulitan. Dalam prakteknya penerapan strategi ini memberikan hasil yang cukup signifikan dalam mencapai 
tujuan pembelajaran yang telah direncakan dan ditetapkan baik dari sisi akademis maupun psikologis antara pendidik dan peserta didik.

\section{Tantang Pendidik dalam Menerapkan Strategi Umpan Balik}

Setelah membahas penerapan umpan balik dalam pelaksanaannya juga terdapat beberapa kendala atau tantangan selama proses penerapannya. Kendala atau tantangan yang dimaksud adalah waktu diluar jam mengajar yang harus disediakan oleh pengajar/pendidik. Dalam ha ini pendidik harus bersedia memberikan atau menyediakan waktu dan tenaga baik itu dalam menyediakan soalsoal latihan ataupun ikut hadir didalam pertemuan kelompok-kelompok yang telah dibentuk. Disisi lain pendidik juga harus terus mengontrol dan terus mengawasi setiap kelompok melalui mentor sebaya, apakah proses pembelajaran pada setiap kelompok berjalan sesuai dengan yang diharapkan atau tidak. Pendidik juga diharapkan mampu menjalin komunikasi yang baik dengan para mentor atau pun anggota kelompok karena pengajar akan mengontrol masing-masing kelompok melalui laporan mentor sebaya. Tantangan atau kendala selanjutnya adalah kekurangan jumlah mentor sebaya yang akan menjadi mentor pada masing-masing kelompok atau dimungkinkan pendidik/pengajar tidak menemukan mentor yang dianggap tepat. Tantangan berikutnya adalah pendidik/pengajar harus membuat atau menyediakan soal-soal tes/kuis yang akan diselenggarakan disetiap pekan jadwal mengajar. Selanjutnya adalah akan ada beberapa peserta didik yang memiliki tingkat pemahaman rendah sehingga diperlukan waktu yang cukup banyak untuk mengatasinya. Kemudian akan ada peserta didik yang cuek/tidak peduli terhadap segala aktifitas proses belajar mengajar di kelas. Lalu akan ada peserta didik yang kurang memiliki motivasi untuk belajar.

\section{PENUTUP}

Strategi pembelajaran adalah salah satu bagian terpenting yang harus disusun dan ditentukan terlebih dahulu sebelum memulai proses belajar mengajar. Strategi pembelajaran yang baik akan menentukan hasil pembelajaran yang baik pula. Dalam hal ini strategi umpan balik dapat menjadi salah satu pilihan yang digunakan dalam proses belajar mengajar karena dalam strategi tersebut menekankan pada aspek evaluasi dan tes pemahaman materi pada akhir pengajaran. Disisi lain juga antara kedua objek dari proses belajar mengajar yakni para peserta didik dan pendidik harus berkolaborasi dan memiliki kemampuan, waktu dan komitmen yang cukup baik dalam mewujudkan proses belajar mengajar yang maksimal untuk mencapai gol atau tujuan belajar mengajar yang telah direncanakan dan ditetapkan. 


\section{DAFTAR PUSTAKA}

Dick, W \& Carey, L. 1994. The Systematic Design of Instruction. New York: Harper Collins.

Haryoko, S. 2011. Efektivitas Strategi Pemberian Umpan Balik Terhadap Kinerja Praktikum Mahasiswa D-3 Jurusan Teknik Elektronika. Jurnal Cakrawala Pendidikan. Vol.30 No.1. pp. 103-115.

Irons, A. 2008. Enhancing Learning through Formative Assessment and Feedback. USA and Canada: Routledge Taylor \& Francis e- Library.

Peraturan Menteri Pendidikan Nasional Nomor 41 Tahun 2007 Tentang Standar Proses Pendidikan.

Pupuh dan Sobri, 2009. Strategi Belajar Mengajar. Bandung: PT Reka Jaya. Sudjana, N. 1989. Dasar-Dasar Proses Belajar-Mengajar. Bandung: Sinar Baru.

Stevens, D.D., Levi, A. 2005. Introduction to Rubrics: an Assessment Tool to Save Grading Time, Convey Effective Feedback, and Promote Student Learning. Canada: Stylus Publishing, LLC.

Sudjana, N. 1989. Dasar-Dasar Proses Belajar Mengajar. Bandung: Sinar Baru.

Sunhaji. 2008. Strategi Pembelajaran: Konsep dan Aplikasinya. Jurnal Pemikiran Alternatif Pendidikan. Vol.13. No.3. pp 474-492.

Windarsih, C. A. 2016. Aplikasi Teori Umpan Balik (Feedback) Dalam Pembelajaran Motorik Pada Anak Usia Dini. E-Journal STKIP Siliwangi. Vol.2. No.1. pp.20-29. 